\title{
A Review Paper: Critical Factors Affecting the Development of ICT Projects in Malaysia
}

\author{
Chew Chun Meng ${ }^{1}$, Bahaman Abu Samah ${ }^{1} \&$ Siti Zobidah Omar $^{1}$ \\ ${ }^{1}$ Laboratory of Cyber Generation, Institute for Social Science Studies, Universiti Putra Malaysia, Malaysia \\ Correspondence: Chew Chun Meng, Laboratory of Cyber Generation, Institute for Social Science Studies, \\ Universiti Putra Malaysia, Malaysia. Tel: 60-3-8947-1852. E-mail: alisacmchew@gmail.com
}

Received: December 26, 2012 Accepted: February 19, 2013 Online Published: March 28, 2013

doi:10.5539/ass.v9n4p42

URL: http://dx.doi.org/10.5539/ass.v9n4p42

\begin{abstract}
Malaysia has been stuck at middle-income level since the 1990s. Hence, the government has been aggressively undertaking productivity improvement by enhancing its technological and knowledge capabilities in order to transform the community into a knowledge-based society. However, more than $40 \%$ of its population still lives in rural areas and lack basic infrastructure (such as fixed telephone lines or Internet connection). This has led to a wider information gap between the rural and urban communities. The setting up of telecentres is seen as a means by which to bridge this gap, as it will provide public access to ICT services and facilities, particularly in remote areas where such services and facilities are lacking. Malaysia has systematically planned a framework to narrow down the gap; it attempts to offer the best ICT infrastructure to its people, thereby allowing them to adopt ICT as a tool to improve their social-economic status. Although investments and efforts have been in place, however, some of these projects have yet to prove successful, and many projects are still in a developmental stage. In addition, there are few empirical studies on the critical issues surrounding the formation of ICT projects in Malaysia, and we are in dire need of research to fill this gap. This paper provides a discussion of the relevant documents, and a literature analysis, regarding the catalysts and barriers towards the development of ICT projects.
\end{abstract}

Keywords: ICT projects, critical issues, telecentre development

\section{Introduction}

Information and Communication Technologies, commonly known as ICT, can be described as a variety of goods, applications and services. That can be used for creating, disseminating, processing and transforming information (e.g. TV, radio broadcasting, hardware and software, computer services and electronic media) (Marcelle, 2000). In other words, the use of ICT can accelerate and enhance the dissemination and sharing of information and facilitates the communication processes, across vast, geographically dispersed areas.

According to a recent report by The World Bank Group (2012), ICT can effectively be used for overcoming poverty, increasing business productivity, accelerating economic growth and improving accountability and governance in any society. Thioune (2003) emphasises that ICT plays an important role in improving different aspects of people's lives. For example the use of ICT could positively impact on economic growth, education, communication, and mobility, as well as providing opportunities for positive development. Developing countries, like Malaysia, have been inspired by the successful stories of most developed countries, and have adopted ICT as part of their national development strategies (e.g. ICT development policies in Malaysia).

The Internet is a key enabler of ICTs, whether that is in terms of accessibility to networking (e.g. Facebook, LinkedIn, twitter, etc.,) obtaining and sharing knowledge, disseminating information, and developing of e-based activities (e.g. e-billing, e-bank, online shopping, etc.). Recognizing the importance and power of knowledge and information, the government in Malaysia and private investors lead a number of initiatives to provide rural and underserved communities community with telecentres and e-centres (CeCs) (UNESCAP, 2006). These initiatives have contributed to increased internet access for people living outside urban areas and it are expected to increase use of internet in rural areas as tool for improving people's means and livelihood

More specifically in Malaysia the National IT Agenda (NITA) under Third Outline Perspective Plan (2001-2010) and the Multimedia Super Corridor (MSC) under the Eighth Malaysia Plan (2001-2005) were established for the 
development of the global ICT industry, in line with the objective of Vision 2020 (Note 1). Such establishments are expected to act as a firm basis on which to maintain a positive rate of economic growth and strengthen international competitiveness. Currently, there are more than two thousand telecentres developed by government agencies, institutions of higher learning, NGOs and private initiatives with different approaches, frameworks, and/or models (Nor Fariza et al., 2012). However, despite this aggressive rolling out of telecentres across the country, there are only a few studies that have identified what have been the critical issues affecting the development of ICT projects in the rural communities. Thus the aim of this study is to review the literature and identified the factors that have facilitated or hindered the positive development of these telecentres, so that the necessary improvements or adjustment can be made.

\subsection{ICT Development Policies in Malaysia}

Since Malaysia gained independence in 1957, it underwent a structural transformation from an agriculture- and mining-based economy to a manufacturing-based economy in the 1980s to 1990s. It is currently heading towards to an innovation-based economy which is driven by knowledge and technology. In the past, Malaysia's wealth was mainly derived from its natural resources, labour force and accumulated capital base. With the rapid information revolution and advancement of ICT globally, Malaysia has vigorously promoted the use and development of ICT as the new form of the nation's wealth, and has put increasing emphasis on knowledge in its various embodied forms.

Malaysia thus initiated the shift from an input-driven strategy to a productivity-driven mode to sustain its future growth. One of the nine central strategic challenges outlined by Tun Mahathir Mohamed, former prime minister of Malaysia, is to generate a scientific and progressive community; this not only emphasizes the users of technology, but also inventors of scientific and technological advancements for future generations (Musa \& Hasim, 2008). This policy has been carried on by Dato' Seri Abdullah Ahmad Badawi, followed by Dato' Seri Najib Razak who took over in 2009. Consequently, the National ICT Council (NITC) was established under the Sixth Malaysian Plan (1990-1995) to initiate and execute the NITA. The NITC, was created to support Vision 2020 in which IT development has been prioritized as the main tool to achieve the transformation of community into a knowledge-based society

Another project introduced as part of NITA was the Multimedia Super Corridor (MSC). The MSC was established in 1996 to create an ideal IT and multimedia environment, as well as a global test-bed to allow Malaysia to become the hub of knowledge and information for workers, technopreneurs and high-technology industries. To achieve this, five cybercities, namely Kuala Lumpur City Centre (KLCC), Kuala Lumpur Tower, Technology Park Malaysia, Cyberjaya and Malaysian Technology Development Corporation-Universiti Putra Malaysia Incubator Centre have been established. The MSC's pivotal role is to power Malaysia's transformation into a global knowledge and innovation hub (Vicziany \& Marlia, 2004). In line with the establishment of these cybercities, a number of ICT-based projects or schemes have been initiated, these are listed below:

- MyCard

- Telemedicine

- Electronic government

- Research and development cluster

- Smart schools

- Worldwide manufacturing web

- Borderless marketing.

These ICT-based projects or schemes aim to facilitate everyday task for Malaysian citizens. Similarly, Malaysia's Universal Service Provision (USP) Policy, launched under the terms of the Communications and Multimedia Act 1998, involved planning and implementing programmes to underserved areas, where ICT applications and services are not sufficiently available. Therefore, the main aim of USP is to ensure that all communities have equal access to basic telephony and Internet services.

Although initially USP aimed to install basic fixed lines and public telephony devices to underserved communities, the Malaysian Government included Internet service accessibility, into the various USP phases. For example the Ministry of Health, Ministry of Education, Malaysia Library, and State National Libraries have cooperated with MCMC to develop projects like rural libraries and clinics.

Currently, the Tenth Malaysian Plan (2011-2015) (10MP) continues recognizing the vital role of ICT for taking Malaysia from a middle-income nation to a high-income nation, eliminating the digital bridge that divides rural 
and urban areas by enhancing the standards of receiving information nationwide. Under the 10MP, the government aims to achieve a $75 \%$ of household broadband penetration rate by 2015 .

\subsection{ICT Projects in Malaysia}

Internet usage in Malaysia began around 1992, with the first internet provider Jaring (Salman and Hasim, 2009). Nonetheless, it was later on when Internet penetration took place in suburban communities, as result of (1) public- and private-sector initiatives, such as telecentres, Pusat Internet Desa (rural Internet centres) which aim to increase the rate of diffusion; and (2) the distribution of netbooks with broadband access under the 1Malaysia Netbook programme to students from low-income households.

Telecentres, originally known as "telecottages" were first introduced in the 1980s in developed countries, for example the Europe's telecottage, the Electronic Village Halls originally in Denmark, and the Community Technology Centers (CTCs) in the United States (Nor Fariza et al., 2012). These Telecentre were first established as "knowledge centres" for the community, and offer public access to ICT-based services and applications (Ariyabandu, 2009). This idea of Telecentres has been implemented in other developed and developing countries. Commonly, telecentres are equipped with telephones, fax machines, email platforms, Internet, computers, CD-ROMs, printers, photocopiers, meeting spaces and so on.

The general aim of telecentres is to advance computer education and provide adequate access to information, which can be utilized as a catalyst for developing the nation's socio-economic status, particularly with respect to aspects germane to economy, education, government information, healthcare and other services (Harris, 2007). Telecentres can serve to increase the sharing of ICT across communities, particularly those in rural areas with a lack of Internet penetration (Ibrahim et al., 2009).

The telecentres in Malaysia are funded by a number of sources, including the federal and state governments, NGOs, and the private sector (Salman \& Hasim, 2009). In relation to that, among the numerous of ICT projects that have been established, "Medan Info Desa" (MID), "Community Broadband Center" and "Rural Internet Center" are the most "attached" telecentres projects to the rural community. Though the success of these telecentres has been proven in a number of studies (Badsar et al. 2011; Rao, 2008; Noor Bathi, 2005), only a small number of centres have been proven to be sustainable (UNESCAP, 2006). 
Table 1. The current status of the telecentres in Malaysia

\begin{tabular}{|c|c|c|c|c|c|}
\hline No. & $\begin{array}{l}\text { Type of } \\
\text { Telecentre }\end{array}$ & $\begin{array}{l}\text { Number of } \\
\text { Telecentres } \\
\text { (as of } \\
\text { March } \\
\text { 2011) }\end{array}$ & Objectives & Target Group & $\begin{array}{l}\text { Management } \\
\text { Structure }\end{array}$ \\
\hline 1 & $\begin{array}{lr}\text { Pusat } & \text { Internet } \\
\text { Desa } & \text { (PID)/ } \\
\text { Rural } & \text { Internet } \\
\text { Center } & \text { by } \\
\text { Ministry } & \text { of } \\
\text { Energy, } & \text { Water, } \\
\text { and } & \\
\text { Communication } \\
(2000)\end{array}$ & 42 & $\begin{array}{l}\text { To bridge the digital divide between rural and } \\
\text { urban communities through shared facilities } \\
\text { with computers and internet access. Provide } \\
\text { classes and seminars. }\end{array}$ & $\begin{array}{l}\text { Women } \\
\text { Senior citizens } \\
\text { Youth } \\
\text { Students } \\
\text { Entrepreneurs } \\
\text { Government and private } \\
\text { sector employees } \\
\text { Small and medium } \\
\text { businesses }\end{array}$ & $\begin{array}{l}\text { Post office } \\
\text { (annex). } \\
\text { Supervised by a } \\
\text { manager and } \\
\text { assistant. }\end{array}$ \\
\hline 2 & $\begin{array}{l}\text { Medan Infodesa } \\
(\mathrm{MID}) \text { by } \\
\text { Ministry of } \\
\text { Rural and } \\
\text { Regional } \\
\text { Development } \\
(2001)\end{array}$ & 236 & $\begin{array}{l}\text { To create a knowledgeable society by } \\
2020 \text {. } \\
\text { To provide equal opportunities to all } \\
\text { communities with respect to ICT. } \\
\text { To attain a knowledge-based economy. }\end{array}$ & $\begin{array}{l}\text { Individuals (local } \\
\text { community members) } \\
\text { Small businesses } \\
\text { Schools } \\
\text { Youth } \\
\text { Disabled people } \\
\text { Farmers } \\
\text { Women's groups } \\
\text { Political parties } \\
\text { Government departments }\end{array}$ & $\begin{array}{l}\text { Management } \\
\text { Board (chaired } \\
\text { by a District } \\
\text { Officer), } \\
\text { consisting of } \\
\text { members of the } \\
\text { community. A } \\
\text { manager and four } \\
\text { trainers. }\end{array}$ \\
\hline 3 & $\begin{array}{l}\text { Community } \\
\text { Broadband } \\
\text { Center (CBC)/ } \\
\text { Pusat Jalur Lebar } \\
\text { Kommuniti by } \\
\text { Malaysian } \\
\text { Communication } \\
\text { \& Multimedia } \\
\text { Commission } \\
\text { (MCMC) (2010) }\end{array}$ & 246 & $\begin{array}{l}\text { Provide ICT services to the community in } \\
\text { rural areas, e.g. WIFI access, training } \\
\text { programmes, IT-related events. } \\
\text { Bridge digital divide and prime society for } \\
\text { the information age }\end{array}$ & $\begin{array}{l}\text { Children } \\
\text { Women } \\
\text { Adults } \\
\text { Entrepreneurs } \\
\text { Senior citizens }\end{array}$ & $\begin{array}{l}\text { Supervised by a } \\
\text { manager and } \\
\text { assistant } \\
\text { manager. }\end{array}$ \\
\hline
\end{tabular}

Sources: UNESCAP (2006)

Medan Infodesa (MID): one-stop ICT centre for rural communities by the Ministry of Rural and Regional Development, Malaysia (2007)

Dimension, progress and key issues in bridging digital divide by Ministry of Rural and Regional Development Malaysia. ADOC 2.0 Workshop (2011)

\section{Critical Issues in the Development of ICT Projects in Malaysia}

A considerable number of studies have focused on identifying key factors that facilitate and hasten the process of developing ICT projects, especially telecentres, in rural communities within developing countries (Badsar et al., 2011; Abu Hassan et al., 2008; Omar et al., 2008; Wan Rozaimi et al., 2007; Noor Bathi, 2005). Based on the literature reviewed, the most commonly reported critical issues in the development of ICT projects in Malaysia are related to, but not exclusive, the quality and availability and maintenance of infrastructure, community involvement, ability to meet local needs and interests, numbers of staff needed to handle tasks and 
responsibilities, seminar and courses provided, partnerships with other entities.

\subsection{Infrastructure and Maintenance}

Technology infrastructures are the facilities and equipment to be used in telecentres and are important means of building a knowledgeable society (Badsar et al., 2011). According to the literature reviewed, the quality and availability of services need to be placed as a top priority in developing telecentres. The main factors for infrastructure sustainability are: connectivity, stability, business continuity, demand-oriented infrastructure, perceived centre security and insurance, maintenance and supply of IT equipment. Internet accessibility and connection is key enabler for remote areas for accessing information from the global information network, therefore, poor telephone lines and poorly maintained infrastructure and electricity supply should be avoided. In addition to IC, IT equipment such as printers, scanners, fax machines etc. should be provided, depending on the objectives and budget of each telecentres.

There are a number of issues related to poor Infrastructure and maintenance of telecentres in Malaysia; for example, insufficient ICT resources, inadequate maintenance and repair of telecentres and IT equipment (Wan Rozaini et al. 2007; Noor Bathi, 2005). Roman and Colle (2002) argue that many ICT projects have been initiated without a firm plan for long-term sustainability. Therefore, some of the available telecentres might not have the appropriate recourses to maintain their IT equipment.

\subsection{Community Involvement}

Norizan (2009) identified as one of the key factors that could contribute with narrowing the digital gap the active participation, involvement and support from the community towards telecentres. Through the strong support from the community, users, committee members, and the local champion (e.g. local leaders, politicians or state representatives) any decisions made could be successfully implemented by the telecentres operators. Community involvement could also ensure that planned ICT activities are carried out and encourage people to participate in such activities. Rao's (2008) reports that in India community involvement enhanced the telecentres' sustainability. Moreover, Kanungo (2004) indicates that collective ownership of a telecentre could ensure access to everyone regardless of social status. He also affirms that the leadership and participation on telecentres is crucial in ensuring different and innovative ideas with respect to narrowing the gaps. Roman and Colle $(2002,12)$ also emphasizes the important of community participation in telecentre projects:

“ it conveys a sense of community ownership it provides indigenous wisdom;

it helps reflect community values and will help us identify information needs; it

provides important resources, such as volunteers or technical expertise, at a favorable cost;

and some people need the telecentre's services."

Similarly, Roman and Colle (2002) state that in order to create a successful telecentre, community partnerships and participation, as well as community relevance should be considered.

\subsection{In Line with Local Needs and Interests}

The projects should be relevant to the community needs and interests; it is essential to carefully tailor and maintain an infrastructure that fits local needs and offers a supportive learning environment that enables engagement and empowerment that in turn are instrumental in achieving a knowledge-based economy (Colle, 2002).

Most local services would run a needs assessment prior to the initial implementation of infrastructure and equipment, in order to understand the needs of current and potential customers. According to Noor Bathi (2005) it is important that telecentres invest on publicity and trained IT staff that could educate the community in the usage of ICT in their everyday lives..

Roman and Colle (2002) argue that one of the universal barriers to access ICT services is illiteracy; communities will face limitations in accessing ICT services and training programmes if they are illiterate. The content of the services and programmes on offer need to be relevant and avoid unfamiliar languages, and irrelevant information to the local context. In addition, learning or using new technology might cause anxiety or fear for some members of the population, and this technophobia results in hindering the broad use of ICT. Furthermore unfamiliar and complex Internet and computer procedures can be intimidating, and raise subsequent impediments to rural users. (e.g. psychological stress, anxiety). Several researchers claim that the best way to identify the needs and the relevant contents for the communities is a participatory approach in which local organizations and community representatives are involved (Baron, 1999; Robinson, 1999; Scharffenberger, 1999). 


\subsection{Adequate Numbers of Staff and Related Training/Courses}

Having an adequate number of administrative staff is crucial for telecentre sustainability (Wan Rozaini et al., 2007; Hazita et al., 2007). Telecentre staff are not only agents of delivering quality services to customers, but also they are responsible for generating the telecentres' income. Thus, staff should receive continuous training, have a proper salary, and be encouraged to learn new skills, as this can assist in achieving the telecentres' objectives. Furthermore, qualified staff and managers are essential for the development of telecentres and integrating ICT into the programmes. It is equally important for the telecentre staff to understand and internalize and the core values, vision and mission of the operating telecentre. Badsar et al. (2011) show that the competency of leaders with adequate qualifications and experience contributes significantly to telecentres' success. And Bashir et al. (2011) confirm that leaders' competency and capacity to manage telecentres effectively, and their ability to ensure that the infrastructure functions adequately, are vital factors in the success of developing telecentres.

A study conducted by Norizan et al. (2010) on the effectiveness of the training programs offered at the telecentre shows that a standard training program and evaluation procedures are needed. Also Norizan and colleagues (2010) reported that training in ICT related skills, development strategies, staff roles, production of content, marketing, evaluation, human resource management are important components in ensuring the sustainability of the telecentre. Roman and Colle (2002), point out that most emphasize has been posited on computer-related skills, while other skills related to community development and socio-economic issues have received relatively less attention. However telecentre are expected to work in hand with the community, thus they should at least have basic understanding of community development and socio-economic issues.

\subsection{Partnerships with Other Entities}

Organizational sustainability can be explained as relying on a suitable ownership and leadership pattern, the effective promotion of telecentres, human networking, and strategic business planning and documentation. Building a motivated, enthusiastic and sustainable partnership between the government, private sectors and local community is crucial as it can generate efficient telecentres, while enhancing their sustainability. Moreover, according to Ariyabandu (2009), telecentres' success can be impeded by a poor level of involvement of governments and communities in promoting and adopting the usage of ICT; limited creativity and innovative thinking; and poor business models or failures to set out the objectives of the organization.

Colle (2005) states community organizations such as health centers, agricultural extension agents etc. should build partnership with telecentres and join efforts in identifying the needs of the communities so that they can satisfy the demand for telecentre services. In addition, telecentre staff should be able to reach out to local community groups and demonstrate how telecentre resources can be applied to business, government and development of activities. For example, in China and Hungary telecentres have successfully established links with local government or private organizations resulting in the enhancement of telecentres sustainability (Colle, 2005) .

\subsection{Systematic Financial Planning}

Telecentre finance must be carefully planned and should be invested in creative ways. Previous studies have confirmed that a lack of financial support has caused many telecentres to face sustainability problems in Malaysia (Norizan \& Jalaluddin, 2008). According to Ibrahim et al. (2010), financial support is the key element for operating and maintaining telecentres. Telecentres are generally dependent on public funds at least in their initial stages. Ibrahim and colleagues (2010) show that more than three quarters of the telecentres in Malaysia are given inadequate budgets, hence hindering the extent to which they can deliver benefits and services to the marginalised society. Ariyabandu (2009) stresses that the problem of telecentres' dependency on subsidies, can be overcome with systematic financial planning, and telecentres should be given the chance to administer and plan their own budgets, as this will aid them to thoroughly plan their finances in accordance with the telecentres' needs and capacities.

\subsection{Other Considerable Factors}

According to available empirical data on telecentre projects that operates in different countries there are 10 major factors related to telecentre sustainability (Roman \& Colle, 2002):

1) Commitment from policy makers

2) Transforming policy into action 
3) Hiring suitable and influential persons who are capable of encouraging others to understand the objectives of telecentres;

4) Engaging volunteers to operate the telecentres

5) Fostering cooperation between telecentres, as this can help them to advance and share a variety of resources

6) Raising awareness of the importance of ICT as a source of information in this modern day

7) Conducting research relevant to telecentres

8) Conducting sustainability and long-term financial planning paired to community interests

9) Focusing on information services that fit community interests, with a larger base for generating income

10) Encouraging community involvement via a strategic approach.

\section{Conclusion}

ICT and Internet literacy are tools by which the Malaysian government can transform the country into a high-income economy country. A series of important issues are interrelated with the operation and management of successful telecentres. For example the infrastructure and its maintenance, community partnerships and participation, content and services relevant to community needs and interests, properly trained staff \& manager, partnerships with local government and private investors and good financial planning.

ICT is a means to an end, and not an end in itself, as it works as a tool and enabler to accelerate development. The value created via ICT is to aid the different sectors in using technology to disseminate information and knowledge and improve accessibility. Thus, solely depending on investment and use of ICT is not a solution to economic growth. Telecentres are seen as the starting point from which the government can achieve the transformation of the country into a knowledge-based economy and a knowledge-society, while encouraging the usage of ICT services in people's everyday lives.

In summary, factors that will improve services and ensure service relevance sustainability include conducting service needs assessments, considering the local context and using the local language, providing reasonable pricing, and offering promotional activities, educational workshops and user training and assistance. Technology infrastructures are important means of are the facilities and equipment to be used in telecentres. Thus it should be made available to rural and underserved communities via financial subsidies and support from the local government and private sectors in building a knowledgeable society. To avoid relying too heavily on government money, telecentres need to have their own initiatives to generate finances. In other hand, any government efforts to reduce Internet rates for rural communities create a substantial cost for the national economy. Telecentre staff are not only agents of delivering quality services to customers, but also they are responsible for generating the telecentres' income. Hence, training and courses are important because inadequate human capital will result in problems regarding management of the telecentres in long run telecentre sustainability.

Besides sustainability, consideration should be given to government policy, business planning, and telecentres' objectives (Yusop et al., 2010). In addition, rural communities play an important role in embracing the policies and programmes implemented by the government.

Telecentres play a role in narrowing the existing information gap between the urban and rural population; thus, rural development is crucial in helping the government to make Malaysia a developed country by 2020. Progress will have no meaning if there are regions or people who fall behind in certain areas following government efforts to develop the country.

\section{References}

Abu Hassan, M., Omar, S. Z., Bolong, J., \& Ismail, N. (2008). Kesan terhadap peserta yang mengikuti projek ICT di luar bandar. Pertanika Journal Social Science and Humanities, 16(1), 85-94.

Ariyabandu, R. (2009). Role of telecentres as knowledge networks: successes and challenges. Information and Communication Technology and Disaster Risk Reduction Division, United Nations ESCAP, United Nations Building, Rajdamnern Nok Avenue, Bangkok, 10200.

Badsar, M., Samah, B. A., Hassan, M. A., Osman, N. B., \& Shaffri, H. A. (2011). Predictor factors of telecentres outcome from the users perspectives in rural communities. American Journal of Applied Sciences, 8(6), 617-627. http://dx.doi.org/10.3844/ajassp.2011.617.627

Baron, L. F. (n. d.). Experiements in Community Access to New Communication and Information Technologies in Bogota, in Telecentre Evalaution: A Global Perspective. Retrieved from 
http://www.idrc.ca/telecentre/evaluation $/ \mathrm{html} / \mathrm{main} \cdot \mathrm{html}$

Bashir, M. S., Samah, B. A., Emby, Z., Badsar, M., Shaffril, H. M., \& Aliyu, A. U. (2011). Information and Communication Technology Development in Malaysia: Influence of competency of leaders, location, infrastructures and quality of services on telecentre success in rural communities of Malaysia. Australian Journal of Basic and Applied Sciences, 5(9), 1718-1728.

Colle, R. (2005). Memo to telecentre planners. The Electronic Journal of Information Systems in Developing Countries, 21, 1-13.

Economic Planning Unit. (2001). Eighth Malaysia Plan 2001-2005. Retrieved from $\mathrm{http} / / /$ www.epu.gov.my/html/themes/epu/.../8th_msia_plan_c13_cont.pdf

Harris, R. W. (2007). Telecentre evaluation in the Malaysian context. Paper presented at the 5th International Conference on IT in Asia, 10-12 July 2007, Kuching, Sarawak, Malaysia.

Hazita, A., Siti Hanim, S., Jamilah, M., Tg Nor Rizan, T. M. M., Noraza, A. Z., Kalthum, I., ... Zaini, A. (2007). Peranan Pusat e-komuniti terhadap Pembangunan Kemahiran: eLiterasi di Kalangan Warga Belia Luar Bandar. Paper presented at E-Community Research Center Coloqium, 8 February 2007, Bangi, Selangor, Malaysia.

Ibrahim, H., Yasin, A., \& Dahalin, Z. (2010). Financial sustainability issues in Malaysia's telecentres. Computer and Information Science, 3(2), 235-240.

Ibrahim, Z., Sulaiman, A., \& Faziharudean. T. M. (2009). The roles of community based telecenters in bridging the digital divide in rural Malaysia. International Journal of Humanities and Social Sciences, 4(5), 371-383.

Kanungo, S. (2004). On the emancipatory role of rural information systems. Information Technology and People, 17(4), 407-422. http://dx.doi.org/10.1108/09593840410570267

Marcelle, G. M. (2000). Getting gender into African ICT policy: A strategic view. Gender and the Information Revolution in Africa, 35-84.

Musa, A. H., \& Hasim, M. S. (2008). My Malaysia. In F. Libero (Ed.), Digital Review of Asia pacific 2007-2008. SAGE Publications, India Pvt Ltd.

Noor Bathi, B. (2005). Draft Rural ICT Guidebook - Based on Malaysian Experience. Paper presented at the Regional Meeting on Effective Design and Delivery of Rural Community ICT Services by UNESCAP/INTAN, 2005, INTAN Bukit Kiara, Kuala Lumpur, Malaysia.

Nor Fariza, M. N., Norizan, A. R., \& Jalaluddin, A. M. (2012). Telecenters as training centers of e-learning for the marginalized community: the Malaysian experience. WSEAS Transactions on Information Science and Applications, 5(9), 147-157.

Norizan, A. R. (2009). Empowering the rural communities via the telecentres. European Journal of Social Sciences, 9(3), 425-432.

Norizan, A. R., \& Jalaluddin, A. M. (2008). Bridging Digital Divide in Malaysia: Cyber Learning for the Marginalized Community. Paper presented at the Distance Learning and Internet Conference, 19-22 November, 2008, Tokyo, Japan.

Norizan, A. R., Zaharah, H., \& Rosseni, D. (2010). Bridging the Digital Divide: An Analysis of the Training Program at Malaysian Telecenters. Paper presented at The 6th WSEAS International Conference on Applied and Theoretical Mechanics, Athens, Greece. 2010.

Omar, S. Z., Abu Hassan, M., Bolong, J., \& Ismail, N. (2008). Faktor kejayaan dan kegagalan projek ICT di luar Bandar. Pertanika Journal of Social Sciences and Humanities, 16(2), 173-186.

Rao, S. S. (2008). Social development in Indian rural communities: adoption of telecentres. International Journal of Information Management, 28(6), 474-482. http://dx.doi.org/10.1016/j.ijinfomgt.2008.01.001

Robinson, S. R. (1999). On Estimating Telecentre Demand in Mexican Rural Municipios, in Telecentre Evalaution: A Global Perspective. Retrieved from http://www.idrc.ca/telecentre/evaluation $/ \mathrm{html} / \mathrm{main}$.html

Roman, R., \& Colle, R. D. (2002). Themes and issues in telecentre sustainability development informatics. Working Paper Series, Paper No. 10. Institute for Development Policy and Management, University of Manchester, Precinct Centre, Manchester.

Salman, A., \& Hasim, M. S. (2009). Sustainability of Internet usage: A study among Malay women in a sub-urban setting in Malaysia. European Journal of Social Sciences, 9(3), 433-447. 
Scharffenberger, G. (1999). Telecentre Evaluation Methods and Instruments: What works and why? In Telecentre Evalaution: A Global Perspective. Retrieved from http://www.idrc.ca/telecentre/evaluation/html $/ \mathrm{main}$.html

The Third Outline Perspective Plan 2001-2010: Chapter 5. Developing Malaysia into a Knowledge-Based. Retrieved from http://www.epu.gov.my/html/themes/epu/../3rd_OPP_cont_chap5.pdf

The World Bank Group. (2012). ICT for greater development impact: World Bank Group Strategy for Information and Communication Technology. Retrieved from http://www.worldbank.org/.../WBG_ICT_Strategy-2012.pdf.

Thioune, R. M. (Ed.). (2003). Opportunities and Challenges for Community Development (Vol. 1). Codesria.

UNESCAP. (2006). Guidebook on Developing Community E-Centres in Rural Areas: Based on the Malaysian Experience. Retrieved from. http://www.unescap.org/pdd/prs/ProjectActivities/Ongoing/ICT/guidebook.pdf

Vicziany, M., \& Marlia, P. (2004). Vision 2020, the Multimedia Super Corridor and Malaysian Universities. Asia Examined: Proceedings of the 15th Biennial Conference of the Asian Studies Association of Australia. Asian Studies Association of Australia, Inc.

Wan Rozaini, S. O., Zahurin, M. A., Huda, I., Nor Iadah, Y., \& Nafishah, O. (2007). Ke Arah Memperkasakan Komuniti Luar Bandar: Penilaian Situasi Semasa Pusat Internet Desa (PID). Paper presented at E-Community Research Center Coloqium, 8 February 2007, Bangi, Selangor, Malaysia.

Yusop, N. I., Affendi, M., Affendi, S., Mat Aji, Z., Ibrahim, H. H., Kasiran, M., \& Rahmat, A. R. (2010). The influence of community characteristics towards telecentres success. Computer and Information Science, $3(2), 116-120$.

\section{Note}

Note 1. Vision 2020 was created and launched by Tun Mahathir Mohamed, former Malaysia prime minister, as part of the Sixth Malaysian Plan in 1999. It is the blueprint of Malaysia's future, and outlines its plans for the country to become a developed nation by 2020 . 